\title{
The Secularization of the Modern American University
}

\section{Book Review}

George M. Marsden, The Soul of the American University: From Protestant Establishment to Established Nonbelief (New York: Oxford University Press, 1994). 462 pp., \$35.00. ISBN 0-19-507046-1.

\section{J. A. Appleyard, S.J.}

J. A. Appleyard, S.J., is professor of English literature and director of the undergraduate honors program in the College of Arts and Sciences at Boston College. He is also rector of the Jesuit Community at Boston College. Address: The Honors Program, Gasson Hall, Boston College, Chestnut Hill MA 02167.

$\mathrm{I}_{\mathrm{t}}^{\mathrm{t}}$ $t$ is well known that most of the colleges and universities founded in the United States before the 20th century had a strongly religious character, usually Protestant Christian, and that virtually all of these institutions have no significant religious identity today. The best-known example is Harvard, founded "for the provision of a learned ministry," whose motto for three centuries was "Christo et Ecclesiae," but scores of other institutions-including Yale, Princeton, Chicago, Stanford, Duke, Boston University, and even publicly funded state universities such as Michigan and California-had a pronounced Christian character in the early years of their existence, which they abandoned in the 20th century.

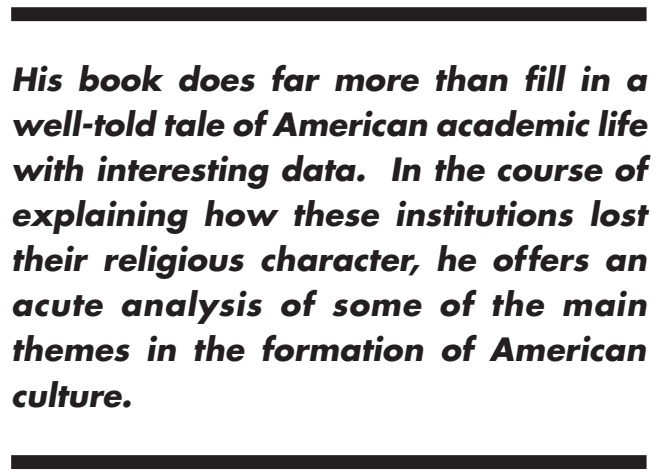

Marsden, a historian of American Protestant religion at the University of Notre Dame, tells the story of this transition in fascinating detail. But his book does far more than fill in a well-told tale of American academic life with interesting data. In the course of explaining how these institutions lost their religious character, he offers an acute analysis of some of the main themes in the formation of American culture. His book is also an account of how American religion and education were profoundly changed by the development of secular modern culture in the wake of the Enlightenment.
Contemporary readers will be surprised at how strongly religious most colleges and universities were in the 18th and 19th centuries. They had clergymen presidents, who defined their identity with a strongly Christian rhetoric. The required curriculum included Scripture and Christian doctrine. They insisted on a doctrinally sound content for sensitive courses (e.g., biology in the face of Darwinism) and often required that faculty be practicing church members in their sect (e.g., the famous historian Frederick Jackson Turner was refused a professorship at Princeton because he was a Unitarian). They sponsored social service programs with a religious character (e.g., the YMCA). Chapel attendance was required of students.

What happened to bring about the changes? Marsden's overall thesis is that the leading figures in these institutions subscribed to the agenda of creating a national, nonsectarian Protestant public culture- at first because this was thought essential for building a nation, especially in the wake of the Civil War, and later because it was a way of resisting the influence of large numbers of non-Protestant and non-Christian immigrants. They succeeded in terms of the national public culture, which was distinctively Protestant until World War II, but in the process the religious identity of their colleges and universities disappeared because nonsectarian Protestantism had little or no content that could withstand the challenges that came from empirical science, claims to academic freedom, and the demand to accommodate an increasing pluralism of beliefs, including nonbelief.

Marsden details the specific changes that fed this process:

- Theology became more liberal and turned by degrees into moral science (under the influence of the Scottish Enlightenment this became the defining characteristic of the curriculum in most late 19th-century colleges).

- Religious sentiment got translated into commitment to public service (Wilson at Princeton), training for democracy (Dewey at Chicago), and the promotion of character.

- The research-oriented German university, with its ideology of empirical and value-free science, became the norm for most expanding American institutions.

- The concept of academic freedom was widened so as to be understood as scientific competence, and was felt to be incompatible with dogmatic belief.

- Religion itself became the object of scientific study. Establishing departments of religion and religious studies became an acceptable way of sequestering the religious di- 
mension of the institution's identity out of any mainstream influence in the institution, a way of avoiding addressing the deeper issues involved.

- Religious tests for faculty hiring were abandoned. The principal norm became competence in one's profession.

- Many institutions abandoned any legal relationship to the founding denominations so as to free themselves from clerical overseers outside the university.

- Some major foundations, conspicuously the Carnegie Endowment, encouraged dropping religious affiliation by offering funding only to nonsectarian institutions.

- Perhaps most significantly, there was no real engagement of an intellectual theology with the issues of the day. This was due in part to the 19th-century Protestant identification of religion with practical morality and with religious sentiment. To put it more strongly, there was even a fairly strong anti-intellectual bias in much of American Protestantism, which estranged increasingly science-oriented scholars from religion.

One of the most poignant claims Marsden makes is that the leaders of American Protestant universities did not intend the secularization their institutions ultimately underwent.

One of the most poignant claims Marsden makes is that the leaders of American Protestant universities did not intend the secularization their institutions ultimately underwent. Indeed, they insisted that the changes they were instituting for particular short-term benefits would actually strengthen the Christian character of their institutions. They seem not to have understood the forces they were yielding to. Their conception of religion led them to identify with the mainstream culture rather than to offer a prophetic criticism of it. In the end, these institutions did not have an intellectual theology or a view of education healthy enough to engage the powerful influences of modernity on equal terms.

The result is the contemporary situation, characterized not only by the disestablishment of Protestantism in the university but also by the virtual establishment of nonbelief. And Catholic colleges and universities, which entered the American academic mainstream only after World War II, are wondering whether they will repeat the same secularizing process. The phenomenon of secularization noted by Marsden is clearly visible in Catholic universities today. One aspect of this is the tendency to identify the religious element of institutional life with the theology department, campus ministry, and student service programs. Another-and perhaps the more important, as it feeds the first-is that faculty hiring in the major universities is almost completely done at the departmental level and follows the criterion of the best possible person as defined by the standards of the profession. The result is a dramatic gulf between older (usually Catholic) faculty, and younger colleagues, for whom religious belief is largely irrelevant to scholarship and teaching.

Still, there are reasons for thinking that Catholic institutions may resist the trend Marsden describes. The rich Catholic theological and moral tradition is still relatively strong in U.S. Catholic culture as a whole (e.g., in books, periodicals, and newspapers). There is still a presumption that public life should be subject to evaluation from a religious perspective. Thus, Catholic intellectual life still has something of an outsider quality, which resists complete assimilation (e.g., on issues such as abortion, war, social justice, and euthanasia). Moreover, the assumption that faith and learning are intrinsically connected is still frequently voiced by leaders in Catholic education and plays a role in the rhetoric by which Catholic institutions define themselves. And Catholic intellectuals evince a strong interest in learning from men and women of other religious backgrounds and cooperating in common agendas. Finally, worshipping communities and a pastoral concern for students' spiritual as well as intellectual development are still features of Catholic colleges and universities.

What can Catholic universities do to nourish their religious identity? I suggest:

- that they develop institutional structures that strengthen the connections between religious faith and learning — such as strong theology departments, endowed chairs with this focus in each discipline, cross-disciplinary institutes that pursue the dialogue between faith and culture (and draw faculty from different disciplines into this dialogue), and courses and curricular programs that initiate students into this dialogue;

- that they have strong campus ministry programs;

- that they develop ways of introducing new faculty and staff into the ethos of the institution and of enabling experienced faculty and staff to reflect on how their disciplines are related to broader issues of community, culture, and belief; and

- that they make a point of identifying themselves as Catholic institutions (to the public and especially to prospective faculty, staff, and students) precisely in terms of these kinds of structures and programs that distinguish them from other universities. 